\title{
Discovery of Oosporein as a New Inhibitor of Influenza Virus Cap- snatching Activity
}

Nobuhiro Koyama ${ }^{1,2^{\star}}$, Yoshio Shibagaki ${ }^{3}$, Mitsuru Okuwaki ${ }^{3}$, Seisuke Hattori ${ }^{3}$ and Hiroshi Tomoda ${ }^{1,2^{\star}}$

${ }^{1}$ Department of Microbial Chemistry, Graduate School of Pharmaceutical Sciences, Kitasato University, Japan

${ }^{2}$ Medicinal Research Laboratories, School of Pharmacy, Kitasato University, Japan

${ }^{3}$ Division of Biochemistry, School of Pharmacy, Kitasato University, Japan

\section{Abstract}

During our screening of microbial origins, we found that fungal strain BF-0073 produces an inhibitor of the cap-snatching activity of influenza virus. Compound (1) was isolated from the culture broth of fungal strain BF-0073 by solvent extraction and preparative HPLC. Based on structural analyses using MS and NMR, 1 was identified as oosporein. Compound 1 inhibited the cap-snatching activity of influenza virus A in a dose-dependent manner, with an $\mathrm{IC}_{50}$ value of $20.0 \mu \mathrm{g} / \mathrm{mL}$.

\section{Publication History:}

Received: June 10, 2020

Accepted: July 04, 2020

Published: July 06, 2020

\section{Keywords:}

Oosporein, Inhibitor, Influenza virus, Cap-snatching activity
Our research group has focused on the discovery of new compounds from microbial sources due to their great chemical diversity and interesting biological activity [1-5]. Original assays systems were used to screen our culture collection for bioactive compounds. Over 1,000 microbial samples were screened, and fungal strain BF-0073 was selected for producing an inhibitor of the cap-snatching activity of influenza virus. Seven-day-old culture broth $(200 \mathrm{~mL})$ of this strain was extracted with an equal volume of ethanol, and the extract was collected by suction filtration and then evaporated in vacuo to obtain a water fraction. The water fraction was extracted with ethyl acetate $(200 \mathrm{~mL})$ and then concentrated in vacuo to yield a crude extract $(275.6 \mathrm{mg})$. The crude extract was dissolved in a small volume of methanol and further purified by HPLC using a reverse-phase C18 column (PEGASIL ODS SP100, i.d. $20 \times 250 \mathrm{~mm}$ ) under the following conditions: solvent, $25 \%$ aq $\mathrm{CH}_{3} \mathrm{CN}$ containing $0.05 \% \mathrm{TFA}$; flow rate, $6.0 \mathrm{~mL} / \mathrm{min}$; detection, UV at $210 \mathrm{~nm}$. Under these conditions, the active compound was eluted as a peak with a retention time of $28 \mathrm{~min}$. This fraction was collected, concentrated in vacuo, and lyophilized to dryness to yield pure compound $\mathbf{1}(15.3 \mathrm{mg})$ as a purple powder. The structure was elucidated by spectroscopic data, including NMR experiments. Compound $\mathbf{1}$ was identified as oosporein based on comparisons with previously reported data [6] (Figure 1). ${ }^{1} \mathrm{H}-\mathrm{NMR}$ $\left(400 \mathrm{MHz}\right.$, pyridine- $\left.d_{5}\right): \delta 1.70(\mathrm{~s}, 3 \mathrm{H}) .{ }^{13} \mathrm{C}-\mathrm{NMR}(100 \mathrm{MHz}$, pyridine- $d_{5}$ ): $\delta 8.1,106.1,107.4,171.9,173.4$. ESI-MS: [M-H] ${ }^{-}: 305$.

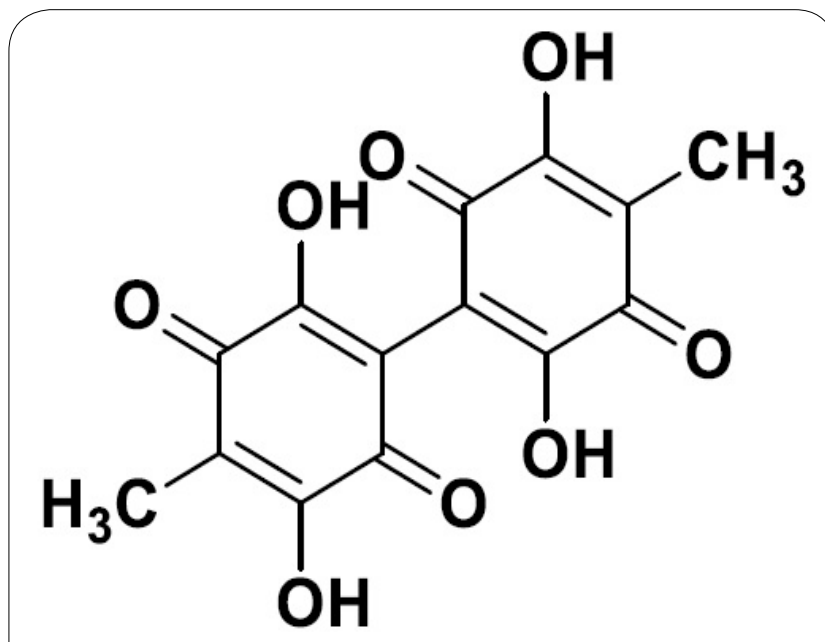

Figure 1: Structure of oosporein.
The effects of 1 on the cap-snatching activity of influenza virus were evaluated according to previously established methods [7-9]. Briefly, a reaction mixture $(25 \mu \mathrm{L})$ containing $50 \mathrm{mM}$ Tris- $\mathrm{HCl}(\mathrm{pH}$ 7.9), 0.1 $\mathrm{M}$ ammonium acetate, $1.5 \mathrm{mM} \mathrm{MgCl}, 2.5 \mathrm{mM}$ DTT, $0.1 \%$ Nonidet P-40, 4U of RNasin, and 30-50 fmol of [ $\left.{ }^{32} \mathrm{P}\right]$ Cap 1-GACU $\mathrm{G}_{32}$-biot $(2 \times$ $10^{5} \mathrm{cpm} / \mathrm{pmol}$ ) was incubated with influenza virus A virions $(1 \mu \mathrm{g})$ at $37^{\circ} \mathrm{C}$ for $1 \mathrm{~h}$. The reaction was stopped by incubation withbuffer $(200$ $\mu \mathrm{L}$ ) containing $20 \mathrm{mM}$ Tris- $\mathrm{HCl}$ ( $\mathrm{pH} 8.0$ ), 5 mM EDTA, $150 \mathrm{mM} \mathrm{NaCl}$, and streptavidin beads $(30 \mu \mathrm{g})$ at room temperature for $10 \mathrm{~min}$. The streptavidin beads-bound and unbound fractions were then collected separately, and the radioactivity of each was measured to calculate the corresponding $\mathrm{IC}_{50}$ value. Compound $\mathbf{1}$ inhibited cap-snatching activity in a dose-dependent manner by suppressing the generation of the cleaved fragment from [ $\left.{ }^{32} \mathrm{P}\right] \mathrm{Cap} 1-\mathrm{GACU}_{32}$-biot. The calculated $\mathrm{IC}_{50}$ value was $20.0 \mu \mathrm{g} / \mathrm{mL}$ (Figure 2), which was comparable to that of a known inhibitor of cap-snatching activity described in the literature, 2-hydroxy-4-oxo-4-phenyl-2-butenoic acid [10].

In conclusion, we identified oosporein produced by the fungal strain BF-0073 as an inhibitor of influenza virus cap-snatching activity. Terry et al. reported that the compound inhibited DNA polymerase of herpes simplex virus type 1 with an $\mathrm{IC}_{50}$ value of $22.9 \mu \mathrm{g} / \mathrm{mL}$ [11]. Interestingly, oosporein had no observable effect on DNA polymerase of HeLa cells or Escherichia coli, confirming the DNA polymerase selectivity of these organisms. Further study is needed to determine whether inhibition of the cap-snatching activity of influenza virus and DNA polymerase of herpes simplex virus type I occurs via a similar mechanism.

"Corresponding Author: Dr. Nobuhiro Koyama, Department of Microbial Chemistry, Graduate School of Pharmaceutical Sciences, Kitasato University, 5-9-1 Shirokane, Minato-ku, Tokyo 108-8641, Japan; E-mail: koyaman@pharm.kitasato-u.ac.jp

"Corresponding Author: Dr. Hiroshi Tomoda, Department of Microbial Chemistry, Graduate School of Pharmaceutical Sciences, Kitasato University, 5-9-1 Shirokane Minato-ku, Tokyo 108-8641, Japan; E-mail: tomodah@pharm.kitasato-u.ac.jp

Citation: Koyama N, Shibagaki Y, Okuwaki M, Hattori S, Tomoda H, et al. (2020) Discovery of Oosporein as a New Inhibitor of Influenza Virus Cap-snatching Activity. Int J Pharma Sci Res 7: 137. doi: https://doi.org/10.15344/24564028/2020/137

Copyright: (c) $2020 \mathrm{Mal}$ et al. This is an open-access article distributed under the terms of the Creative Commons Attribution License, which permits unrestricted use, distribution, and reproduction in any medium, provided the original author and source are credited. 


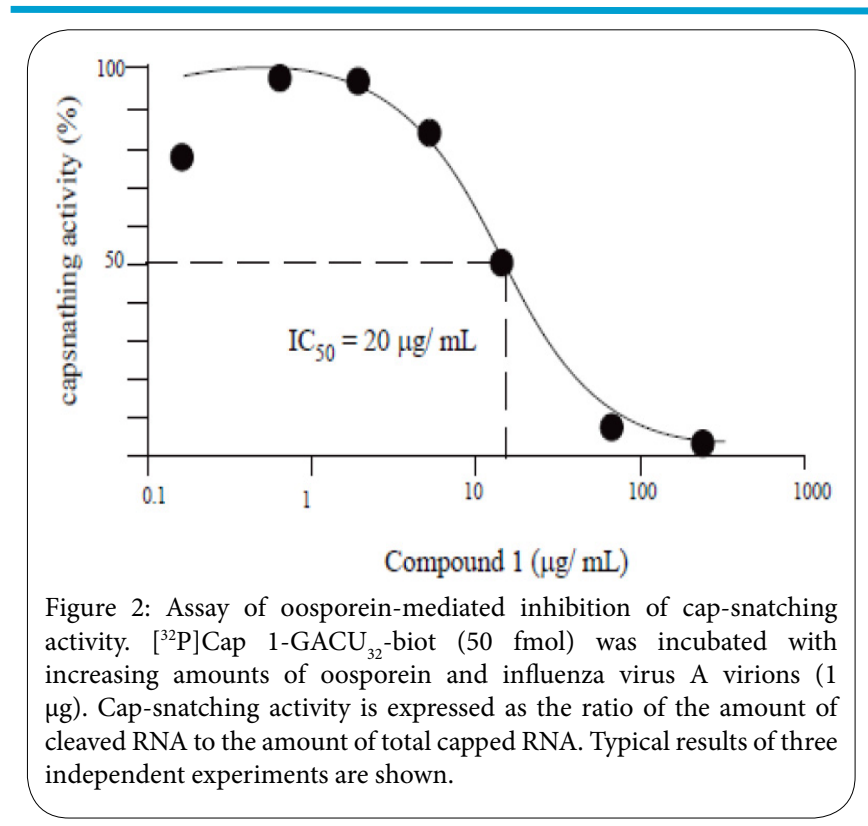

\section{Acknowledgments}

We thank Ms. Aya Niijima, Ms. Shino Masuo, and Ms. Haruka Mio, School of Pharmacy, Kitasato University, for their assistance. We express our thanks to Ms. Noriko Sato and Dr. Kenichiro Nagai, School of Pharmacy, Kitasato University, for NMR and MS analyses, respectively.

\section{Funding}

This work was supported by grant $15 \mathrm{~K} 07867$ (NK) from the Ministry of Education, Culture, Sport, Science, and Technology, Japan.

\section{Competing Interests}

The authors declare that they have no competing interests.

\section{References}

1. Koyama N, Shigeno S, Kanamoto A, Tomoda H (2020) Steffimycin E, a new anti-mycobacterial agent against Mycobacterium avium complex, produced by Streptomyces sp. OPMA02852. J Antibiot 73: 581-584.

2. Koyama N Tomoda H (2019) MS network-based screening for new antibiotics discovery. J Antibiot (Tokyo) 72: 54-56.

3. Floros DJ, Jensen PR, Dorrestein PC, Koyama N (2016) A metabolomics guided exploration of marine natural product chemical space. Metabolomics 12: 145.

4. Tominaga T, Uchida R, Koyama N, Tomoda H (2018) Anti-Rhizopus activity of tanzawaic acids produced by the hot spring-derived fungus Penicillium sp. BF-0005. J Antibiot 71: 626-632.

5. Hosoda K, Koyama N, Kanamoto A, Tomoda H (2019) Discovery of Nosiheptide, Griseoviridin, and Etamycin as Potent Anti-Mycobacterial Agents against Mycobacterium avium Complex. Molecules 24:E1495.

6. Love BE, Bonner-Stewart J, Forrest LA. (2009) An efficient synthesis of oosporein. Tetrahed Lett 50:5050-5052.

7. Shibagaki $Y$, Ikuta N, Iguchi S, Takaki K, Watanabe $\mathrm{S}$, et al. (2014) An efficient screening system for influenza virus cap-dependent endonuclease inhibitors. J Virol Methods 202: 8-14.

8. Klumpp K, Hooker L, Handa B (2001) Influenza virus endoribonuclease. Methods Enzymol 342: 451-466.
9. Wakai C, Iwama M, Mizumoto K, Nagata K (2011) Recognition of cap structure by influenza B virus RNA polymerase is less dependent on the methyl residue than recognition by influenza A virus polymerase. J Virol 85: 7504-7512.

10. Tomassini J, Selnick H, Davies ME, Armstrong ME, Baldwin J, et al. (1994) Inhibition of cap (m7GpppXm)-dependent endonuclease of influenza virus by 4-substituted 2,4-dioxobutanoic acid compounds. Antimicrob Agents Chemother 38: 2827-2837.

11. Terry BJ, Liu WC, Cianci CW, Proszynski E, Fernandes $P$, et al. (1992) Inhibition of herpes simplex virus type 1 DNA polymerase by the natural product oosporein. J Antibiot 45: 286-288. 